\title{
Is Socially Responsible Indices Weak Form of Efficient Market? Evidences from Developing Economies
}

\author{
Sabyasachi Mondal ${ }^{1} \&$ Ranjit Singh ${ }^{1}$ \\ ${ }^{1}$ Department of Management Studies, Indian Institute of Information Technology, Deoghat, Jhalwa, Allahabad, \\ Uttar Pradesh, India \\ Correspondence: Ranjit Singh. E-mail: ranjitsingh@iiita.ac.in
}

Received: October 30, 2019

Accepted: November 30, 2019

Online Published: January 31, 2020

doi:10.5539/ass.v16n2p55

URL: https://doi.org/10.5539/ass.v16n2p55

\begin{abstract}
The study is an attempt to identify the presence of randomness in the socially responsible indices (SRI) of the stock markets of developing countries. Five developing economies are considered for the test of randomness on daily, weekly, monthly, quarterly and semiannual return of socially responsible indices and their benchmark indices. Shapiro-Wilk test is used to test the normality of the data whereas Runs test and Augmented Dickey-Fuller test are used depending on the randomness of the data. It is observed that India, Arab and Egypt show non-randomness whereas Brazil and South Africa show randomness in daily returns. Weekly returns on the other hand are random in Brazil, Arab, South Africa, and non-random in India and Egypt. Monthly and quarterly returns show randomness in India, Arab, Egypt, South Africa and non-randomness in Brazil whereas semiannual returns show randomness for all economies. It is also observed that most socially responsible indices resonate the randomness patterns of their benchmark indices. Most of the non-randomness is seen in short-run indicating inefficiency in the market. However, in long-run, the market goes random or efficient which is an indication that more than average profit can be earned by resorting to technical trading in the short run. Moreover, the similarity in randomness between socially responsible indices and their benchmark indices indicates that similar trading strategy can be applied by traders in both these indices to garner profit.
\end{abstract}

Keywords: Augmented Dickey-Fuller test, normality, market efficiency, randomness, Runs test, Shapiro-Wilk test

\section{Background of the Study}

Efficient market Hypothesis' (EMH) suggests that, all the information pertinent to a security gets reflected in its price at any given point of time. As a result, an investor cannot find any undervalued or overvalued stock through the process of technical analysis. Hence, financial markets are 'informationally efficient' (Fama, 1970). Among the three form of EMH namely weak, semi strong and strong, weak form of EMH has garnered more attention among the three and technical analysts tried to refute the theory of randomness by earning above average return. Researchers such as Fama and French (1988); Alexeev and Tapon (2011) and Singh, Leepsa and Kushwaha (2016) have tested the weak form of hypothesis to find the randomness of the data taking stock market indices as samples. Researchers have tested the weak form of EMH on several indices such as thematic indices which includes indices such as Islamic index, carbon index, sustainable index etc; sectorial indices which include indices such as banking index, oil and gas index, pharma index etc. Of late, a new index is added to all the stock exchanges in the world which is popularly known as Socially Responsible Index (SRI). Since it is a new edition of stock index, there is little study done on various aspects of it.

The terms SRI is synonymous with ethical investing or value based investing (Sandberg et al. 2009). The earlier phrase of ethical investing is slowly being replaced by socially responsible investing (Sparkes, 2001). Though the definition of SRI varies across individuals, the concept of it summarizes all the desirable non-financial impact of an investment (Dorfleitner \& Utz, 2012). SRI integrates the ethical, social and environmental concern into the investment process (Sandberg et al., 2009). The concept of SRIs has gained more importance since 2008 financial crisis which was largely attributed to the downfall of corporate ethical practices across USA (Puaschunder, 2016).

In the mean time, since 1997, Global Reporting Initiative (GRI) ${ }^{1}$ has created a positive clout among different stakeholders of sustainability including governments and other organizations to make companies report their 
sustainable initiatives. Later, in 2009, United Nations sustainable stock exchange (UNSSE) initiative started pooling stock exchanges, investors and representatives around the world under one platform to promote long-term sustainable investment and improved disclosure in Environmental, Social and Corporate Governance (ESG) Indices. Both these initiatives have fueled increased participation among stock exchanges in creating SRIs across the world.

Corporate social responsibility (CSR) practices lead to higher financial performance and in turn higher stock prices(Liao, Fan and Shih, 2019).Historically, quantum of research on CSR is more in developed countries than in emerging ones. However, due to gap in efficient social provision and governance, need of CSR activities is more pronounced in developing countries (Dobers \& Halme, 2009). In this circumstance, companies are expected to fill those gaps (Baughn et al., 2007). Increase in CSR practices among companies coupled with UNSSE initiative is expected to increase the number of SRI indices in developing countries. It is imperative, hence, to test the efficiency of SRIs in developing countries so that international portfolio managers interested in socially responsible investments find an alternate investment destination to park their money.

Efficient market hypothesis states that only normal returns can be earned by investing in any stock or index in any stock market including socially responsible indices. However, Amenc, Goltz \& Tang (2010) demonstrated that social responsibility of the investor acts as a driving force in deriving higher return for its investors. Eccles, Ioannou, and Serafeim (2011) and Tripathi and Bhandari (2012) observed that companies following environmental and social policies religiously tend to outperform other stocks that do not follow any environmental and social policies. A socially responsible firm needs to look after a diverse group of stakeholders relating to environment, society and governance of the firm without compromising on earning handsome profit for its shareholders (AON, 2007). Geczy, Stambaugh, and Levin (2005) demonstrated that investing in SRI mutual funds incurs a sizeable penalty in certainty-equivalent returns in comparison to mutual funds without such focus. Hong and Kacperczyk (2009) figured that the "sin" firms with sizeable business in tobacco, alcohol and gambling industries earn significantly higher profits than comparable firms in other industries. However, Kempf and Osthoff (2007) and Statman and Glushkov (2009) explained that so called ethical stocks or stocks with higher corporate social responsibility attained significantly higher profits. It has been seen that though there is potential downside risk in investing on these funds, investors tend to bear that cost for ethics (Renneboog, Horst, and Zhang, 2008). A study on European market demonstrated that return on the emission allowances in European markets are serially correlated making it random (Daskalakis, 2008). All these discussion generate a question that is the behavior of socially responsible indices across the world is same as that of traditional indices in terms of randomness?

The security market efficiency proposition forms the basis of most research in the area of finance (Summers, 1986). Shiller (1981) however concluded that the volatility in stock market is much more than can be justified by real economic events due to presence of irrationality. Tversky and Kahneman (1981) have stated that 'irrational decision making' exists in speculative markets. Irrationality among investors leads to derivation of above average profit in a stock market and it violates the basic tenets of EMH. This has inspired ample researches world over to test efficiency in stock markets. However, the advent of thrust in social and environmental issues in the last decade has necessitated research on efficiency of socially responsible indices. Out of 78 countries under the UNSSE initiative of sustainable stock indices though, only 39 have an SRI index. Out of which only five emerging countries have publicly available data for more than 5 years and, hence, data for these five countries are considered to test the efficiency of socially responsible index of their respective stock exchanges.

Since there is a little literature on efficient market hypothesis on socially responsible index, an attempt is made to investigate the possibility of generating more than normal return in socially responsible indices and their benchmark indices and thereby testing weak form of EMH in 14 selected countries of the world. Though researchers did not get much success in refuting the random walk theory and EMH as a whole, they still continue to play an important role in modern finance. Kratz (1999) demonstrated the relevance of EMH for the portfolio managers in outperforming benchmarks and forming adept strategies to exploit market inefficiencies. Clarke, Jandik \& Mandelker (2001) concluded that EMH plays vital role in regulatory authorities, investors and academicians in analyzing investment and financial decisions in the context of emerging markets.

\section{Literature Review and Research Gap}

\subsection{Literature Review}

Bachelier (1964) worked on randomness of speculative prices by testing it on Government bond prices of France. Kendall (1953) and Moore (1964) have worked on the stock price behavior and independence of price differences of securities. The area got a fillip when Granger and Morgenstern (1963) used a new method called 
Spectral analysis which has been used in other fields including study of sound waves to test the random walk hypothesis on NYSE. However, the most prominent work of the decade was done by Fama (1965) who used autocorrelation test and non-parametric runs test to show the randomness of the behavior of share prices.

In the mean time, plethora of statistical technique on the behavior of security prices have shown little evidence that successive prices are related. Few studies have tried using different 'filter' trading rules to trace out the profitability among them such as Fama and Blume (1968) and Alexander (1961). Jensen and Benington (1970) have shown that it is not possible to derive above average profit over the buy and hold strategy. Hence, the empirical validity of random walk model was maintained. Rao and Mukherjee (1971) worked on finding the randomness of Indian stocks taking the daily data of Indian Aluminum Company's shares for the period 1955-70 using spectral analysis. Another comprehensive work in this field was done by Cooper (1982) who studied daily, weekly and monthly data for 36 countries using runs test and spectral analysis and found that returns from US and UK were random and non random for other countries. DeBondt and Thaler $(1985,1987)$ attributed inefficiency in NYSE to market over-reaction to corporate action news about the listed companies. Lo and Mackinlay (1988) studied the weekly return of NYSE stocks and found presence of autocorrelation.

Panas (1990) examined the presence of efficiency in the Athens stock market and found its presence. Frennberg and Hansson (1993) tested the random walk hypothesis using data from Swedish stock market for the period 1919 to 1990 and couldn't find the presence of random walk. Urrutia (1995) examined and concluded that emerging markets are less efficient than the developed market.

Yen and Lee (2008) argued that if necessary precautions are maintained, EMH will play an important role in modern finance. Borges (2010) tested EMH in various financial markets all over the world, under various forms (weak, strong and semi strong) and under different economic conditions (crisis/ recovery periods taking the daily and weekly data). The EMH was rejected for Portugal and Greece due to presence of positive autocorrelations in the data and France and UK rejected the EMH due to mean reversion in weekly data. In another instance, EMH was rejected in ASEAN stock markets using daily returns (Gupta, 2011).

Of late, there were a few studies in respect of sustainable indices as well. Singh, Leepsa, \& Kushwaha (2016) found that sustainable indices from the respective stock exchanges in India, USA, Japan and Brazil are nonrandom in daily returns but their monthly returns are randomly distributed. Singh and Leepsa (2016) found that the return from the sustainable indices are not significantly different that from traditional indices. Mynhardt, Makarenk, \& Plastun (2017) found that sustainable indices are less efficient than the traditional ones.

\subsection{Research Gap}

It can be observed from the literature review that randomness of stock returns has been tested mostly in developed countries and lot lesser in developing countries. It can also be noticed in the discussion that socially responsible indices has a very less share in terms of testing of randomness vis-à-vis other indices. It can therefore be concluded that there has been a lack of study on testing Efficient Market Hypothesis on Socially Responsible Indices of developing countries. This has created a research gap and hence, it is pertinent to ask as a researcher whether investing in SRI indices of the stock markets of developing countries will provide the investors an above average return?

\section{Objective of Study}

The objective of the study is given as follows:

a. To investigate if the returns of SRI indices and their benchmark indices of select developing countries follow a random pattern.

\section{Hypotheses of Study}

The following hypotheses are formed to be tested in this study:
a. $\mathrm{H}_{01}$ : The daily returns of SRI indices of select developing countries follow random pattern;
b. $\mathrm{H}_{02}$ : The weekly returns of SRI indices of select developing countries follow random pattern;
c. $\mathrm{H}_{03}$ : The monthly returns of SRI indices of select developing countries follow random pattern;
d. $\mathrm{H}_{04}$ : The quarterly returns of SRI indices of select developing countries follow random pattern;
e. $\mathrm{H}_{05}$ : The semi-annual returns of SRI indices of select developing countries follow random pattern.

\section{Research Methodology}

An efficient market reflects full information on the intrinsic value of the stock instantaneously on market price 
indicating that successive price changes are independent or random in nature (Fama, 1965).Hence, randomness test has to be conducted to check the efficiency of a stock or an index. A number of randomness tests have been performed over the years. Few of them are autocorrelation test, Unit root tests, runs test, filter trading, spectral analysis, heuristics, simulation, variance test ratio, ARCH/GARCH and Hurst exponent. Runs test for non parametric returns and Unit root test for parametric returns have been used for the analysis. Augmented Dickey-Fuller test being the most commonly used unit root test for large samples is chosen for the analysis.

The study is empirical in nature. Socially responsible indices from several countries across the globe are considered in this study. There are different criteria set by the stock exchanges of different countries for considering a stock to be included in socially responsible index. It is pertinent to note that there may be different types of socially responsible indices such as carbon index, social sustainability index, green index etc. All of these indices have been considered for our analysis because different countries have non-identical approach to socially responsible investments. Due to which one country may just concentrate on companies which are emitting less carbon by clubbing them on an environmental theme and forming a green index whereas another country may focus on companies which are more into corporate social responsibility (CSR) and form a socially sustainable index. It is hence important to capture all the approaches in a single analysis to get the robustness.

The study thereafter tests randomness on these indices along with their benchmark indices and if they turn out to be random, the index is said to be weak form of efficient and vice versa. Based on this approach, a research framework has been proposed in Figure 1.

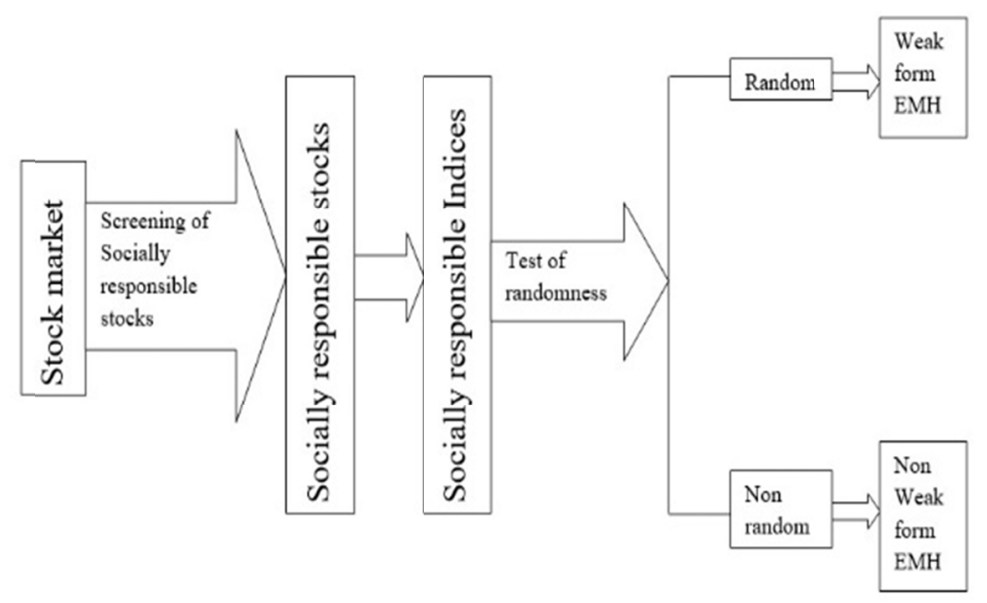

Figure 1. Proposed Research Framework

The study comprises of SRI indices of developing economies. According to United Nation, there is no established definition of developed or developing countries. However, high Gross Domestic Product (GDP) and high Human Development Index (HDI) (prepared by United Nations) are used as tools to define developed countries world over and countries which have failed to attain favorable scores in these two parameters are termed as developing countries. 39 out of 78 countries participating in sustainable stock exchange (SSE) initiative by United Nations have social responsibility index or ESG related index. Out of these 39 countries, only 14 countries have publicly available data for a considerable period of time. Out of these 14 countries, only 5 are considered as developing. These countries are Brazil, India, Arab, Egypt and South Africa. There are other developing countries with SRI Indices including China, Mongolia, Hong Kong and Bangladesh. However, most of these indices have started only in the last 2-3 years owing to the Sustainable Stock Exchange initiative. It resulted in availability of data for a very short period of time for these indices incapacitating them for much analysis. The indices from which the data are collected are given in Table 1.

Table 1. Socially responsible indices (SRI) and their benchmark indices

\begin{tabular}{ccc}
\hline Country & SRI & Benchmark Index \\
\hline Brazil & ICo2 & IBX 50 \\
India & BSE Carbonex & BSE 100 \\
Pan Arab & S\&P ESG Pan Arab & S\&P Pan Arab Composite \\
Egypt & S\&P EGX ESG & EGX 100 \\
South Africa & S\&P SA Composite Carbon & S\&P SA Composite \\
\hline
\end{tabular}

Source: Compiled by authors 


\subsection{Type of Data and Its Collection}

Secondary data extracted from the respective stock exchanges are used in this study. Daily closing prices of the indices mentioned in table 1 are extracted since their inception to $31^{\text {st }}$ December 2018.

\subsection{Data Analysis}

Shapiro-Wilk test (Shapiro \& Wilk, 1965; Nomadiah Mohd Razali, 2011) is used to check the distribution pattern of data to see if it is normally distributed or not. Shapiro-Wilk test is used to assess the goodness of fit if the sample size is less than 2000 (UNT, 2014). Run test, a non-parametric test, is used to test the randomness of return if the data is not normally distributed.A length of run is defined by the number of elements in it. Mean and Variance are calculated as follows.

$$
\begin{gathered}
\text { Mean: } E(R)=(2 N 1 N 2 / N)+1 \\
\text { Variance: } \sigma 2 R=[2 N 1 N 2(2 N 1 N 2-N)] /[(N) 2(N-1)]
\end{gathered}
$$

Where $\mathrm{N}=$ total number of observations $(\mathrm{N} 1+\mathrm{N} 2) ; \mathrm{N} 1=+$ residuals; $\mathrm{N} 2=$ residuals and $\mathrm{R}=$ number of runs.

However, if the data is normally distributed, Augmented Dickey-Fuller (ADF) testis used to determine randomness. The $\mathrm{ADF}$ statistic is represented by the following equation.

$$
\Delta \mathrm{Yt}=\beta 1+\beta 2 \mathrm{t}+\delta \mathrm{Yt}-1+\sum_{i=1}^{m} \alpha_{i} \Delta y_{t-1}+\varepsilon \mathrm{t}
$$

Where $\varepsilon t$ is a white noise error term.For calculating monthly return, the following formula is used:

$\mathrm{Ri}=\mathrm{LN}(\mathrm{Pt} / \mathrm{Pt}-1)$

where

$\mathrm{LN}=$ Logarithmic return

$\mathrm{Ri}=$ The return obtained

$\mathrm{Pt}=$ Price at the end of the day of SRI indices/benchmark market indices

Pt-1 = Price at the end of the day of SRI indices/benchmark market indices.

Logarithm returns are used as they are more likely to be normally distributed which is required for further statistical tests (Strong, 1994). Weekly and monthly data are calculated by averaging the daily data over the number of days in a week and a month respectively. Quarterly and semi-annual data are calculated by averaging the monthly mean over a period of three months and six months respectively. These calculations provided us the set of data on which the next set of analysis has to be done.

\section{Analysis and Findings}

The distributional pattern of closing stock market values for the socially responsible indices and the benchmark indicesfrom 14 selected countries are investigated by the Shapiro-Wilk (SW) test as shown in Table 2.

Table 2. Test of normality (Shapiro Wilk) of log returns of the select indices

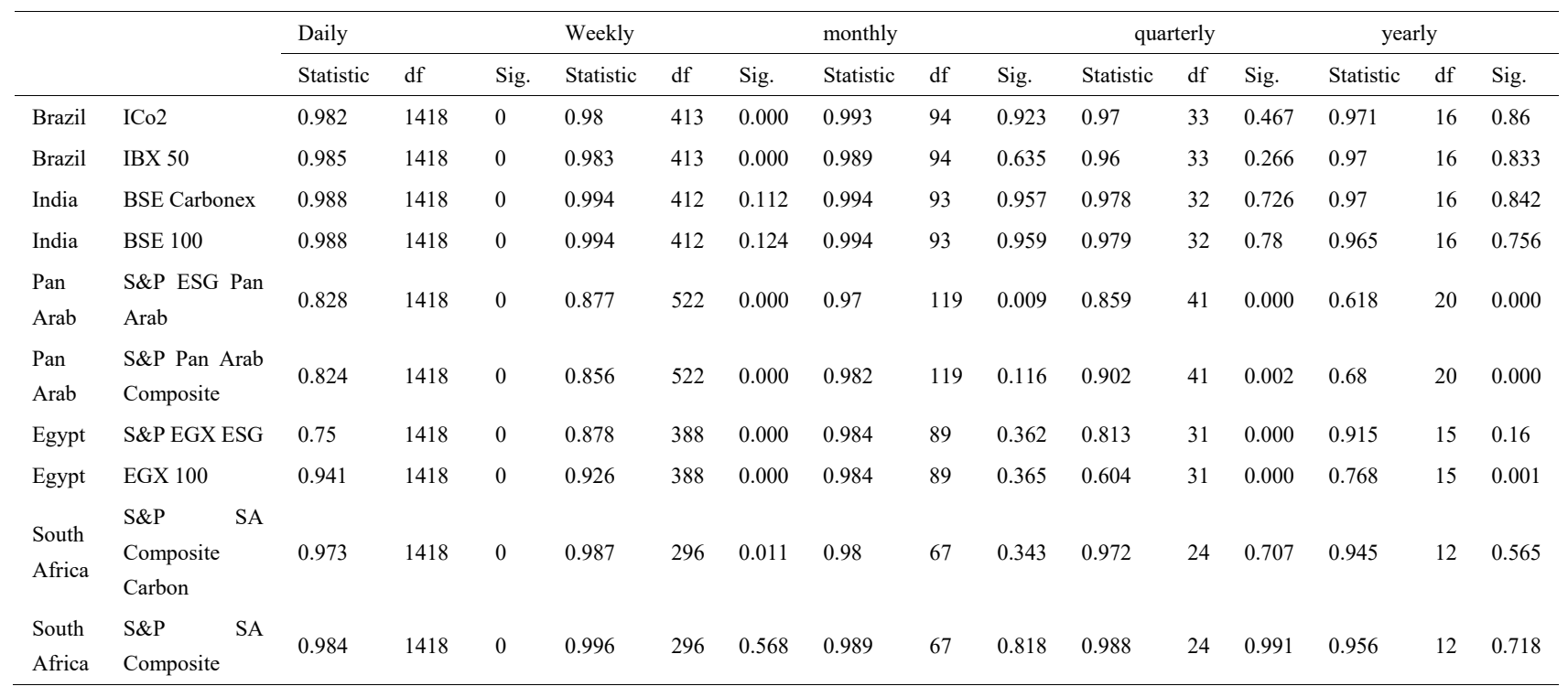

Source: Calculated by authors' from data collected from various sites 
The P-values which are less than 0.05 (5\% level of significance) in table 2 signify that distributions in those indices are not normally distributed, whereas the P-values which are more than 0.05 signifies normal distribution of the returns.

Run test is conducted to test the randomness of returns which is presented in table $3,4,5,6$, and 7 .

Table 3. Runs test on daily returns of select indices

\begin{tabular}{|c|c|c|c|c|c|c|c|c|}
\hline Country & Indices & $\begin{array}{c}\text { Test } \\
\text { Value }\end{array}$ & $\begin{array}{c}\text { Cases }< \\
\text { Test Value }\end{array}$ & $\begin{array}{l}\text { Cases }>= \\
\text { Test Value }\end{array}$ & $\begin{array}{l}\text { Total } \\
\text { Cases }\end{array}$ & $\begin{array}{l}\text { Number } \\
\text { of Runs }\end{array}$ & Z & $\begin{array}{l}\text { Asymp.Sig } \\
\text {. (2-tailed) }\end{array}$ \\
\hline Brazil & $\mathrm{ICo} 2$ & 0.000 & 994 & 994 & 1988 & 976 & 0.852 & 0.394 \\
\hline Brazil & IBX 50 & 0.000 & 994 & 994 & 1988 & 996 & 0.045 & 0.964 \\
\hline India & BSE Carbonex & 0.001 & 981 & 982 & 1963 & 909 & 3.319 & 0.001 \\
\hline India & BSE 100 & 0.001 & 981 & 982 & 1963 & 901 & 3.680 & 0.000 \\
\hline Pan Arab & S\&P ESG Pan Arab & 0.000 & 1660 & 1661 & 3321 & 1475 & 6.474 & 0.000 \\
\hline Pan Arab & S\&P Pan Arab Composite & 0.000 & 1660 & 1661 & 3321 & 1513 & 5.155 & 0.000 \\
\hline Egypt & S\&P EGX ESG & 0.001 & 906 & 907 & 1813 & 816 & 4.299 & 0.000 \\
\hline Egypt & EGX 100 & 0.001 & 906 & 907 & 1813 & 796 & 5.239 & 0.000 \\
\hline South Africa & S\&P SA Composite Carbon & 0.000 & 706 & 712 & 1418 & 706 & 0.212 & 0.832 \\
\hline South Africa & S\&P SA Composite & 0.001 & 709 & 709 & 1418 & 685 & 1.328 & 0.184 \\
\hline
\end{tabular}

Source: Calculated by authors' from data collected from various sites

Table 4. Runs test on weekly returns of select indices

\begin{tabular}{|c|c|c|c|c|c|c|c|c|}
\hline Country & Indices & $\begin{array}{c}\text { Test } \\
\text { Value }\end{array}$ & $\begin{array}{c}\text { Cases }< \\
\text { Test Value }\end{array}$ & $\begin{array}{l}\text { Cases }>= \\
\text { Test Value }\end{array}$ & $\begin{array}{l}\text { Total } \\
\text { Cases }\end{array}$ & $\begin{array}{l}\text { Number } \\
\text { of Runs }\end{array}$ & $\mathrm{Z}$ & $\begin{array}{c}\text { Asymp. Sig. } \\
\text { (2-tailed)a }\end{array}$ \\
\hline Brazil & $\mathrm{ICo} 2$ & 0.001 & 206 & 207 & 413 & 223 & 1.527 & 0.127 \\
\hline Brazil & IBX 50 & 0.001 & 206 & 207 & 413 & 203 & -0.443 & 0.658 \\
\hline India & BSE Carbonex & 0.001 & 206 & 206 & 412 & 194 & -1.282 & 0.200 \\
\hline India & BSE 100 & 0.001 & 206 & 206 & 412 & 194 & -1.282 & 0.200 \\
\hline Pan Arab & S\&P ESG Pan Arab & 0.000 & 261 & 261 & 522 & 241 & -1.840 & 0.066 \\
\hline Pan Arab & S\&P Pan Arab Composite & 0.002 & 261 & 261 & 522 & 237 & -2.191 & 0.028 \\
\hline Egypt & S\&P EGX ESG & 0.001 & 194 & 194 & 388 & 162 & -3.355 & 0.001 \\
\hline Egypt & EGX 100 & 0.001 & 194 & 194 & 388 & 165 & -3.050 & 0.002 \\
\hline South Africa & S\&P SA Composite Carbon & 0.000 & 148 & 148 & 296 & 157 & 0.932 & 0.352 \\
\hline South Africa & S\&P SA Composite & 0.000 & 148 & 148 & 296 & 157 & 0.932 & 0.352 \\
\hline
\end{tabular}

Source: Calculated by authors' from data collected from various sites

Table 5. Runs test on monthly returns of select indices

\begin{tabular}{|c|c|c|c|c|c|c|c|c|}
\hline Country & Indices & Test Value & $\begin{array}{c}\text { Cases }< \\
\text { Test Value }\end{array}$ & $\begin{array}{l}\text { Cases }>= \\
\text { Test Value }\end{array}$ & $\begin{array}{l}\text { Total } \\
\text { Cases }\end{array}$ & $\begin{array}{c}\text { Number of } \\
\text { Runs }\end{array}$ & Z & $\begin{array}{c}\text { Asymp. Sig } \\
\text { (2-tailed) }\end{array}$ \\
\hline Brazil & $\mathrm{ICo} 2$ & 0.000 & 47 & 47 & 94 & 47 & -0.207 & 0.836 \\
\hline Brazil & IBX 50 & 0.000 & 47 & 47 & 94 & 49 & 0.207 & 0.836 \\
\hline India & BSE Carbonex & 0.000 & 46 & 47 & 93 & 53 & 1.148 & 0.251 \\
\hline India & BSE 100 & 0.000 & 46 & 47 & 93 & 53 & 1.148 & 0.251 \\
\hline Pan Arab & S\&P ESG Pan Arab & 0.000 & 59 & 60 & 119 & 51 & -1.749 & 0.080 \\
\hline Pan Arab & S\&P Pan Arab Composite & 0.000 & 59 & 60 & 119 & 53 & -1.380 & 0.168 \\
\hline Egypt & S\&P EGX ESG & 0.000 & 44 & 45 & 89 & 46 & 0.108 & 0.914 \\
\hline Egypt & EGX 100 & 0.000 & 44 & 45 & 89 & 39 & -1.385 & 0.166 \\
\hline $\begin{array}{l}\text { South } \\
\text { Africa }\end{array}$ & S\&P SA Composite Carbon & 0.000 & 33 & 34 & 67 & 33 & -0.368 & 0.713 \\
\hline $\begin{array}{l}\text { South } \\
\text { Africa }\end{array}$ & S\&P SA Composite & 0.000 & 33 & 34 & 67 & 34 & -0.121 & 0.903 \\
\hline
\end{tabular}

Source: Calculated by authors' from data collected from various sites 
Table 6. Runs test on quarterly returns of select indices

\begin{tabular}{ccccccccc}
\hline Country & Indices & $\begin{array}{c}\text { Test } \\
\text { Value }\end{array}$ & $\begin{array}{c}\text { Cases }< \\
\text { Test Value }\end{array}$ & $\begin{array}{c}\text { Cases }>= \\
\text { Test Value }\end{array}$ & $\begin{array}{c}\text { Total } \\
\text { Cases }\end{array}$ & $\begin{array}{c}\text { Number } \\
\text { of Runs }\end{array}$ & $\begin{array}{c}\text { Asymp. Sig. } \\
(2 \text {-tailed })\end{array}$ \\
\hline Brazil & ICo2 & 0.000 & 16 & 17 & 33 & 23 & 1.776 & 0.076 \\
Brazil & IBX 50 & 0.000 & 16 & 17 & 33 & 19 & 0.359 & 0.719 \\
India & BSE Carbonex & 0.000 & 16 & 16 & 32 & 12 & -1.617 & 0.106 \\
India & BSE 100 & 0.000 & 16 & 16 & 32 & 12 & -1.617 & 0.106 \\
Pan Arab & S\&P ESG Pan Arab & 0.000 & 20 & 21 & 41 & 25 & 0.953 & 0.340 \\
Pan Arab & S\&P Pan Arab Composite & 0.000 & 20 & 21 & 41 & 22 & 0.004 & 0.997 \\
Egypt & S\&P EGX ESG & 0.000 & 15 & 16 & 31 & 14 & -0.726 & 0.468 \\
Egypt & EGX 100 & 0.000 & 15 & 16 & 31 & 14 & -0.726 & 0.468 \\
South Africa & S\&P SA Composite Carbon & 0.000 & 12 & 12 & 24 & 12 & -0.209 & 0.835 \\
South Africa & S\&P SA Composite & 0.000 & 12 & 12 & 24 & 13 & 0.000 & 1.000 \\
\hline
\end{tabular}

Source: Calculated by authors' from data collected from various sites

Table 7. Runs test on semiannual returns of select indices

\begin{tabular}{ccccccccc}
\hline Country & Indices & $\begin{array}{c}\text { Test } \\
\text { Value }\end{array}$ & $\begin{array}{c}\text { Cases }< \\
\text { Test Value }\end{array}$ & $\begin{array}{c}\text { Cases }>= \\
\text { Test Value }\end{array}$ & $\begin{array}{c}\text { Total } \\
\text { Cases }\end{array}$ & $\begin{array}{c}\text { Number } \\
\text { of Runs }\end{array}$ & $\begin{array}{c}\text { Z } \\
\text { Zsymp. Sig. } \\
(2 \text {-tailed })\end{array}$ \\
\hline Brazil & ICo2 & 0.000 & 8 & 8 & 16 & 10 & 0.259 & 0.796 \\
Brazil & IBX 50 & 0.000 & 8 & 8 & 16 & 10 & 0.259 & 0.796 \\
India & BSE Carbonex & 0.000 & 8 & 8 & 16 & 8 & -0.259 & 0.796 \\
India & BSE 100 & 0.000 & 8 & 8 & 16 & 8 & -0.259 & 0.796 \\
Pan Arab & S\&P ESG Pan Arab & 0.000 & 10 & 10 & 20 & 12 & 0.230 & 0.818 \\
Pan Arab & S\&P Pan Arab Composite & 0.000 & 10 & 10 & 20 & 10 & -0.230 & 0.818 \\
Egypt & S\&P EGX ESG & 0.001 & 7 & 8 & 15 & 7 & -0.521 & 0.603 \\
Egypt & EGX 100 & 0.001 & 7 & 8 & 15 & 8 & 0.000 & 1.000 \\
South Africa & S\&P SA Composite Carbon & 0.000 & 6 & 6 & 12 & 6 & -0.303 & 0.762 \\
South Africa & S\&P SA Composite & 0.000 & 6 & 6 & 12 & 7 & 0.000 & 1.000 \\
\hline
\end{tabular}

Source: Calculated by authors' from data collected from various sites

$\mathrm{ADF}$ test is conducted to test the randomness of returns on the same data and the result is presented in table 8,9 , 10,11 and 12 .

Table 8 . ADF test on daily returns of select indices

\begin{tabular}{ccccc}
\hline Country & Indices & Dickey-Fuller & Lag order & P value \\
\hline Brazil & ICo2 & -11.043 & 11 & .01 \\
Brazil & IBX 50 & -11.132 & 11 & .01 \\
India & BSE Carbonex & -11.305 & 11 & .01 \\
India & BSE 100 & -11.298 & 11 & .01 \\
Pan Arab & S\&P ESG Pan Arab & -10.624 & 11 & .01 \\
Pan Arab & S\&P Pan Arab Composite & -10.118 & 11 & .01 \\
Egypt & S\&P EGX ESG & -10.907 & 11 & .01 \\
Egypt & EGX 100 & -9.770 & 11 & .01 \\
South Africa & S\&P SA Composite Carbon & -12.602 & 11 & .01 \\
South Africa & S\&P SA Composite & -12.113 & 11 & .01 \\
\hline
\end{tabular}

Source: Calculated by authors' from data collected from various sites

Table 9. ADF test on weekly returns of select indices

\begin{tabular}{ccccc}
\hline Country & Indices & Dickey-Fuller & Lag order & P value \\
\hline Brazil & ICo2 & -7.8698 & 7 & .01 \\
Brazil & IBX 50 & -7.5325 & 7 & .01 \\
India & BSE Carbonex & -8.0551 & 7 & .01 \\
\hline
\end{tabular}




\begin{tabular}{ccccc}
\hline India & BSE 100 & -8.0384 & 7 & .01 \\
Pan Arab & S\&P ESG Pan Arab & -7.1079 & 7 & .01 \\
Pan Arab & S\&P Pan Arab Composite & -6.7466 & 7 & .01 \\
Egypt & S\&P EGX ESG & -6.1507 & 7 & .01 \\
Egypt & EGX 100 & -6.4987 & 7 & .01 \\
South Africa & S\&P SA Composite Carbon & -6.7172 & 6 & .01 \\
South Africa & S\&P SA Composite & -8.0077 & 6 & .01 \\
\hline
\end{tabular}

Source: Calculated by authors' from data collected from various sites

Table 10. ADF test on monthly returns of select indices

\begin{tabular}{ccccc}
\hline Country & Indices & Dickey-Fuller & Lag order & P value \\
\hline Brazil & ICo2 & -4.1269 & 4 & .01 \\
Brazil & IBX 50 & -4.6178 & 4 & .01 \\
India & BSE Carbonex & -3.1421 & 4 & .01 \\
India & BSE 100 & -3.1282 & 4 & .01 \\
Pan Arab & S\&P ESG Pan Arab & -5.4765 & 4 & .01 \\
Pan Arab & S\&P Pan Arab Composite & -4.7307 & 4 & .01 \\
Egypt & S\&P EGX ESG & -3.0439 & 4 & .01 \\
Egypt & EGX 100 & -3.6464 & 4 & .01 \\
South Africa & S\&P SA Composite Carbon & -3.2927 & 4 & .01 \\
South Africa & S\&P SA Composite & -4.3325 & 4 & .01 \\
\hline
\end{tabular}

Source: Calculated by authors' from data collected from various sites

Table 11. ADF test on quarterly returns of select indices

\begin{tabular}{ccccc}
\hline Country & Indices & Dickey-Fuller & Lag order & P value \\
\hline Brazil & ICo2 & -3.8867 & 2 & .029 \\
Brazil & IBX 50 & -3.5703 & 2 & .054 \\
India & BSE Carbonex & -2.3256 & 4 & .448 \\
India & BSE 100 & -2.2883 & 4 & .462 \\
Pan Arab & S\&P ESG Pan Arab & -6.7144 & 2 & .01 \\
Pan Arab & S\&P Pan Arab Composite & -5.5767 & 2 & .01 \\
Egypt & S\&P EGX ESG & -3.364 & 2 & 047. \\
Egypt & EGX 100 & -2.9257 & 2 & .219 \\
South Africa & S\&P SA Composite Carbon & -2.1345 & 2 & .521 \\
South Africa & S\&P SA Composite & -2.119 & 2 & .527 \\
\hline
\end{tabular}

Source: Calculated by authors' from data collected from various sites

Table 12. ADF test on semiannual returns of select indices

\begin{tabular}{ccccc}
\hline Country & Indices & Dickey-Fuller & Lag order & P value \\
\hline Brazil & ICo2 & -3.3483 & 2 & .084 \\
Brazil & IBX 50 & -1.9846 & 2 & .578 \\
India & BSE Carbonex & -1.372 & 4 & .817 \\
India & BSE 100 & -1.3849 & 4 & .806 \\
Pan Arab & S\&P ESG Pan Arab & -1.1629 & 2 & .891 \\
Pan Arab & S\&P Pan Arab Composite & -1.1995 & 2 & .877 \\
Egypt & S\&P EGX ESG & -1.459 & 2 & .7785 \\
Egypt & EGX 100 & -1.4926 & 2 & .765 \\
South Africa & S\&P SA Composite Carbon & -1.6525 & 4 & .704 \\
South Africa & S\&P SA Composite & .2110 & 4 & .99 \\
\hline
\end{tabular}

Source: Calculated by authors' from data collected from various sites

Table 13 shows the synopsis of the normalitytests of the returns of socially responsible indices. 
Table 13. Tests of Normality

\begin{tabular}{cccccc}
\hline & Daily return & Weekly return & Monthly return & Quarterly return & Semiannually return \\
\hline Brazil & Not normal & Not normal & Normal & Normal & Normal \\
India & Not normal & Normal & Normal & Normal & Normal \\
Pan Arab & Not normal & Not normal & Not normal & Not normal & Not normal \\
Egypt & Not normal & Not normal & Normal & Not normal & Normal \\
South Africa & Not normal & Not normal & Normal & Normal & Normal \\
\hline
\end{tabular}

Source: Compiled by authors'

After the test of normality, tests of randomness are conducted. Non-parametric test namely run test is used to test the randomness of returns in case the distribution is not normal and parametric test ofAugmented Dickey Fuller (ADF) is used to test the randomness in case the distribution of returns are normal. Table 15 shows the results of randomness tests for developing countries.

Table 14. Tests of randomness

\begin{tabular}{cccccc}
\hline & Daily return & Weekly return & Monthly return & Quarterly return & Semiannually return \\
\hline Brazil & random & random & nonrandom & nonrandom & random \\
India & nonrandom & nonrandom & random & random & random \\
Pan Arab & nonrandom & random & random & random & random \\
Egypt & nonrandom & nonrandom & random & random & random \\
South Africa & random & random & random & random & random \\
\hline
\end{tabular}

Source: Compiled by authors'

\section{Conclusion and Policy Implications}

It is seen from the analysis that Brazil and South Africa show randomness whereas India, Arab and Egypt show non randomness in daily returns. Weekly returns on the other hand are random in Brazil, Arab, South Africa, and non random in India and Egypt. Monthly returns show randomness in India, Arab, Egypt, South Africa and non randomness in Brazil. Quarterly returns follow the same pattern as monthly returns and show randomness in India, Arab, Egypt, South Africa and non randomness in Brazil. Semiannual returns show randomness in all developing countries. This indicates that the technical trading can be very apt fully applied in the markets, whose return is non-random, to predict future trends in the share prices and thereby increasing the possibility of earning more than normal returns. It is also due to the fact that market most of the time over-reacts to given information and therefore, the prices are either more than the fair value or less than the fair value (Singh, 2011). It is also observed that the returns from the SRIs are getting normal when time period of calculating return is increased from daily to half-yearly. This confirms the findings of Fama (1998), where it was found that market efficiency holds good in the long run.

It is evident that efficiency of the market is not uniform across the countries rather it is specifically different for different countries. This finding is confirming the Adaptive market hypothesis in the socially responsible indices (Lo, 2004). Lo (2004) and Grossman and Stiglitz (1980) argued that there is a presence of arbitrage opportunity in market in contrast to EMH. Without adequate arbitrage opportunity, investors will not get incentivized to gather information. Hence, markets are irrational and it may not be random all time as shown in the analysis above. This is also indicative of existence of seasonality in the SRIs at different point of time (Sah, 2009).

It is observed that investment in socially responsible companies is must for public pension funds and the presence or absence of randomness for different time periods across developed and emerging economies in the analysis provide investment opportunities for socially responsible investors such as pension funds across the globe (Sethi, 2005). Pension funds from USA or Europe can diversify their portfolio by investing in the indices of the emerging economies and derive above average profit in the short run as it fits their strategy.

It is also noticed in the analysis that SRI and benchmark indices behaved in the same pattern. As a result, traders can apply same trading strategy in SRI Indices as applicable to benchmark indices and can earn profit. Thus, by resorting to the trading and investment in SRI indices, the traders/investors can have the profit equal to the benchmark indices and still they have the satisfaction of investing in the stocks which are engaged in socially responsible behavior (Singh and Leepsa, 2016).

In order to promote investment in stocks which show socially responsible behaviour, it is necessary to market such stocks and index and containing such stocks such as SRI index and consequently the risk perception associated with such investment will become favourable (Singh and Bhowal, 2011). In view of this, stock market 
regulator and even the stock market itself can promote investment in SRI Indices through advertisements, online or offline, to mutual fund houses to create SRI mutual funds, index funds or exchange traded funds (ETF). Government should adopt 'nudge' interventions and guide people or institute to behave in a certain way which is beneficial for society (Thaler, 2017). It will eliminate doubt from investors' mind about the profitability of socially responsible indices and on the other hand companies will be encouraged to engage more in ESG practices to make their stock attractive to investors which will add to its market capitalization which is the main objective of any effective financial management strategy. Thus, by resorting to investment in such stocks and indices, returns need not to be compromised and simultaneously the investors will have the satisfaction of investing in the environment and socially-friendly stocks and not doing facilitating in environmental and social degradation by investing in stocks which are not socially responsible. For this, necessary investor education program may be launched by the policy makers (Singh \& Bhowal, 2010a) and these indices need to be made popular using necessary marketing driven approach (Singh \& Bhowal, 2011). Once these stocks and index is familiar to the investors, more flow of investment is expected in these stocks since investors prefer to invest in familiar stocks rather than unfamiliar stocks (Singh and Bhowal, 2010b)

In the aftermath of 2008/2009 World Financial Crisis, the idea of Financial Social Responsibility was needed to be established as a means to instill trust in world financial market and to prevent potential financial market downfall. Socially Responsible Investments (SRI) can be pivotal in this regard (Puaschunder, 2016). The advent of SRI index, hence, is expected to foster financial responsibility among the stakeholders.

\section{Scope of Future Research}

Comparison of return of SRIs and traditional indices can be done to find out the feasibility of investing in SRIs; event study can also be conducted on SRIs to derive suitable conclusion. In future, the number of countries opting for SRIs will be more and hence, a study of similar type can be conducted considering all those countries.

\section{References}

Alexander, S. S. (1961). Price movements in speculative markets: Trends or random walks. Industrial Management Review (pre-1986), 2(2), 7.

Althouse, L. A., Ware, W. B., \& Ferron, J. M. (1998). Detecting Departures from Normality: A Monte Carlo Simulation of a New Omnibus Test Based on Moments.

Alexeev, V., \& Tapon, F. (2011). Testing weak form efficiency on the Toronto Stock Exchange. Journal of Empirical Finance, 18(4), 661-691. https://doi.org/10.1016/j.jempfin.2011.05.002

Amenc, N., Goltz, F., \& Tang, L. (2010). Adoption of green investing by institutional investors: A European survey. France: An EDHEC-Risk Institute.

Tversky, A., \& Kahneman, D. (1981, January). The Framing of Decisions and the Psychology of Choice. Science, 211(January 1981), 453-458. https://doi.org/10.1126/science.7455683

Bachelier, L. (1964). Theory of Speculation, the Random Character of Stock Prices (Translation of Bacheliers 1900 doctoral thesis).

Baughn, C. C., Bodie, N. L. D., \& McIntosh, J. C. (2007). Corporate Social and Environmental Responsibility in Asian Countries and Other Geographical Regions. Corporate Social Responsibility and Environmental Management, 14(4), 189-205. https://doi.org/10.1002/csr.160

Borges, M. R. (2010). Efficient market hypothesis in European stock markets. The European Journal of Finance, 16(7), 711-726. https://doi.org/10.1080/1351847X.2010.495477

Bowman, R. G., \& Buchanan, J. (1995). The efficient market hypothesis-a discussion of institutional, agency and behavioural issues. Australian Journal of Management, 20(2), 155-166. https://doi.org/10.1177/031289629502000203

Clarke, J., Jandik, T., \& Mandelker, G. (2001). The efficient markets hypothesis. Expert financial planning: Advice from industry leaders, 126-141.

Cooper, J. C. (1982). World stock markets: Some random walk tests. Applied Economics, 14(5), 515-531. https://doi.org/10.1080/00036848200000046

Daskalakis, G., \& Markellos, R. N. (2008). Are the European carbon markets efficient. Review of futures markets, 17(2), 103-128.

De Bondt, W. F., \& Thaler, R. (1985). Does the stock market overreact?. The Journal of finance, 40(3), 793-805. https://doi.org/10.1111/j.1540-6261.1985.tb05004.x 
Dobers, P., \& Halme, M. (2009). Corporate social responsibility and developing countries. Corporate Social Responsibility and Environmental Management, 16(5), 237-249. https://doi.org/10.1002/csr.212

Dorfleitner, G., \& Utz, S. (2012). Safety first portfolio choice based on financial and sustainability returns. European Journal of Operational Research, 221(1), 155-164. https://doi.org/10.1016/j.ejor.2012.02.034

Eccles, R. G., Ioannou, I., \& Serafeim, G. (2014). The impact of corporate sustainability on organizational $\begin{array}{llll}\text { processes and performance. } & \text { Management }\end{array}$ https://doi.org/10.1287/mnsc.2014.1984

Fama, E. F., \& Blume, M. E. (1966). Filter rules and stock-market trading. The Journal of Business, 39(1), 226-241. https://doi.org/10.1086/294849

Fama, E. F. (1965). The behavior of stock-market prices. The journal of Business, 38(1), 34-105. https://doi.org/10.1086/294743

Fama, E. F., \& French, K. R. (1988). Permanent and temporary components of stock prices. Journal of political Economy, 96(2), 246-273. https://doi.org/10.1086/261535

Geczy, C., Stambaugh, R., \& Levin, D. (2005). Investing in socially responsible mutual funds.

Statman, M., \& Glushkov, D. (2009). The wages of social responsibility. Financial Analysts Journal, 65(4), 33-46. https://doi.org/10.2469/faj.v65.n4.5

Summers, L. H. (1986). Does the stock market rationally reflect fundamental values?. The Journal of Finance, 41(3), 591-601. https://doi.org/10.1111/j.1540-6261.1986.tb04519.x

Gaunt, C., \& Gray, P. (2003). Short-Term Autocorrelation in Australian Equities. Australian Journal of Management, 28(1), 97-117. https://doi.org/10.1177/031289620302800105

Granger, C. W., \& Morgenstern, O. (1963). Spectral analysis of New York stock market prices 1. Kyklos, 16(1), 1-27. https://doi.org/10.1111/j.1467-6435.1963.tb00270.x

Grossman, S. J., \& Stiglitz, J. E. (1980). On the impossibility of informationally efficient markets. The American economic review, 70(3), 393-408.

Guidi, F., \& Gupta, R. (2011). Are ASEAN stock market efficient? Evidence from univariate and multivariate variance ratio tests. Discussion Papers in Finance, 201113, 488-502.

Frennberg, P., \& Hansson, B. (1993). Testing the random walk hypothesis on Swedish stock prices: 1919-1990. Journal of Banking \& Finance, 17(1), 175-191. https://doi.org/10.1016/0378-4266(93)90087-T

Hong, H., \& Kacperczyk, M. (2009). The price of sin: The effects of social norms on markets. Journal of Financial Economics, 93(1), 15-36. https://doi.org/10.1016/j.jfineco.2008.09.001

Jensen, M. C. (1967). Random walks: Reality or myth-comment. Financial Analysts Journal, 23(6), 77-85. https://doi.org/10.2469/faj.v23.n6.77

Jensen, M. C., \& Benington, G. A. (1970). Random walks and technical theories: Some additional evidence. The Journal of Finance, 25(2), 469-482. https://doi.org/10.1111/j.1540-6261.1970.tb00671.x

Kempf, A., \& Osthoff, P. (2007). The effect of socially responsible investing on portfolio performance. European Financial Management, 13(5), 908-922. https://doi.org/10.1111/j.1468-036X.2007.00402.x

Kendal, M. (1953). The analysis of economic time series, part 1: Prices. Journal of the Royal Statistical Society, 96(1), 11-25. https://doi.org/10.2307/2980947

Krishna Rao, N., \& Mukherjee, K. (1971, January-July). Random-Walk Hypothesis: An Empirical Study. Arthaniti.

Levy, R. A. (1967). Random walks: Reality or myth. Financial Analysts Journal, 23(6), 69-77. https://doi.org/10.2469/faj.v23.n6.69

Lo, A. W. (2004). The adaptive markets hypothesis: Market efficiency from an evolutionary perspective.

Lo, A. W., \& MacKinlay, A. C. (1988). Stock market prices do not follow random walks: Evidence from a simple specification test. The review of financial studies, 1(1), 41-66. https://doi.org/10.1093/rfs/1.1.41

Malkiel, B. G., \& Fama, E. F. (1970). Efficient capital markets: A review of theory and empirical work. The Journal of Finance, 25(2), 383-417. https://doi.org/10.1111/j.1540-6261.1970.tb00518.x

Malkiel, B. G. (2003). The efficient market hypothesis and its critics. Journal of economic perspectives, 17(1), 
59-82. https://doi.org/10.1257/089533003321164958

Mynhardt, R., Makarenko, I., \& Plastun, O. (2017). Market efficiency of traditional stock market indices and social responsible indices: The role of sustainability reporting. https://doi.org/10.21511/imfi.14(2).2017.09

Renneboog, L., Ter Horst, J., \& Zhang, C. (2008). The price of ethics and stakeholder governance: The performance of socially responsible mutual funds. Journal of Corporate Finance, 14(3), 302-322. https://doi.org/10.1016/j.jcorpfin.2008.03.009

Razali, N. M., \& Wah, Y. B. (2011). Power comparisons of shapiro-wilk, kolmogorov-smirnov, lilliefors and anderson-darling tests. Journal of statistical modeling and analytics, 2(1), 21-33.

Kratz, O. S. (1999). Frontier emerging equity markets securities price behavior and valuation. Springer Science \& Business Media.

Liao, L., Fan, Y., \& Shih, M. (2019). What drives social responsibility indices returns? Macroeconomics matters. Corporate Social Responsibility and Environmental Management. https://doi.org/10.1002/csr.1816

Panas, E. (1990). The Behaviour of Athens Stock Prices Applied Economics. Applied Economics, 22, 1715-27. https://doi.org/10.1080/00036849000000077

Puaschunder, J. M. (2016). On the emergence, current state and future perspectives of Socially Responsible Investment (SRI). Current State and Future Perspectives of Socially Responsible Investment (Sri)(January 22, 2016). https://doi.org/10.2139/ssrn.2720686

Poterba, J. M., \& Summers, L. H. (1988). Mean reversion in stock prices: Evidence and implications. Journal of financial economics, 22(1), 27-59. https://doi.org/10.1016/0304-405X(88)90021-9

Puaschunder, J. M. (2016). On the emergence, current state and future perspectives of Socially Responsible Investment (SRI). Consilience: The Columbia University Journal of Sustainable Development, 16(1), 38-63. https://doi.org/10.2139/ssrn.2720686

Sah, A. N. (2009). Stock market seasonality: A study of the Indian stock market. Electronic copy available at: http://ssrn. com/abstract.

Sandberg, J., C. Juravle, T.M. Hedesstro"m, and I. Hamilton. 2009. The heterogeneity of socially responsible investment. Journal of Business Ethics, 87(4), 519-533. https://doi.org/10.1007/s10551-008-9956-0

Sethi, S. P. (2005). Investing in socially responsible companies is a must for public pension funds-because there is no better alternative. Journal of Business Ethics, 56(2), 99-129. https://doi.org/10.1007/s10551-004-5455-0

Shiller, R. Do Stock Prices Move Too Much to be Justified by Subsequent Changes in Dividends? American Economic Review, 71 (June 1981), 421-436. https://doi.org/10.3386/w0456

Singh, R., \& Bhowal, A. (2010a). Imparting investment education to employees by the employer: an expectation-experience gap study. Amity Management Analyst, 5(2), 57-65.

Singh, R., \& Bhowal, A. (2010b). Risk Perception of the Employees with respect to the Equity Shares. The Journal of Behavioural Finance, 11(3), 177-183

Singh, R., \& Bhowal, A. (2011). Development of marketing driven measure of risk perception. The Journal of Risk Finance, 12(2), 140-152.

Singh, R. (2011). Overconfidence in financial decisions: A critical review. IASMS Journal of Business Spectrum, $4(2), 105-114$.

Singh, R., Leepsa, N. M., \& Kushwaha, N. (2016). Testing the weak form of efficient market hypothesis in carbon efficient stock indices along with their benchmark indices in select countries. Iranian Journal of Management Studies, 9(3), 627-650.

Singh, R., \& Leepsa, N. M. (2016). Feasibility of Investing in Carbon Efficient Portfolios. International Journal of Banking and Finance, 12(2), 23-4123-41.

Sparkes, R. (2001). Ethical investment: Whose ethics, which investment? Business Ethics: A European Review 10(3), 194-205. https://doi.org/10.1111/1467-8608.00233

UNT. (2014). Department of Geography. Retrieved Febraury 1, 2014, from http://www.unt.edu/:http://geography.unt.edu/ wolverton/Normality\%20Tests\%20in\%20SPSS.pdf

Urrutia, J. L. (1995). Tests of random walk and market efficiency for Latin American emerging equity markets. 
Journal of financial research, 18(3), 299-309. https://doi.org/10.1111/j.1475-6803.1995.tb00568.x

Welford, R. (2004). Corporate Social Responsibility in Europe and Asia: Critical Elements and Best Practice. Journal of corporate citizenship, (13), 31-47. https://doi.org/10.9774/GLEAF.4700.2004.sp.00007

Worthington, A. C., \& Higgs, H. (2005). Weak-form market efficiency in Asian emerging and developed equity markets: Comparative tests of random walk behaviour.

Yen, G., \& Lee, C. F. (2008). Efficient market hypothesis (EMH): past, present and future. Review of Pacific Basin Financial Markets and Policies, 11(2), 305-329. https://doi.org/10.1142/S0219091508001362

\section{Copyrights}

Copyright for this article is retained by the author(s), with first publication rights granted to the journal.

This is an open-access article distributed under the terms and conditions of the Creative Commons Attribution license (http://creativecommons.org/licenses/by/4.0/).

${ }^{1} \mathrm{GRI}$ is an independent international organization that promotes sustainable reporting among its member countries. 